\title{
HUKUM YANG BERKEADILAN BAGI HAK ULAYAT MASYARAKAT HUKUM ADAT (KAJIAN DAN IMPLEMENTASI)
}

\author{
Verlia Kristiani \\ Mahasiswa Fakultas Hukum Universitas Tarumanagara \\ E-mail: verliakristiani98@gmail.com
}

\begin{abstract}
ABSTRAK
Pemberlakuan Hak Ulayat melalui lahirnya Undang-Undang nomor 5 tahun 1960 tentang Pokok-Pokok Agraria dan Peraturan Menteri Agraria/ Kepala BPN nomor 5 tahun 1999 secara langsung memberikan harapan keadilan terhadap penguasaan dan pemilikan tanah masyarakat Hukum Adat di Indonesia. Namun pada kenyataannya hukum positif yang mengatur mengenai Hak Ulayat ini masih menimbulkan suatu ambivalensi dan belum diatur secara jelas, sehingga pemerintah masih dapat bertindak sewenang-wenang. Hak ulayat yang merupakan hak penguasaan tertinggi masyarakat hukum adat masih sangat sering dikesampingkan, dan bahkan dirampas oleh Pemerintah, seperti pada sengketa perampasan Hak Ulayat yang dilakukan oleh Pemerintah dan PT Freeport pada Suku Amungme di Papua. Dalam pembangunan hukum Agraria, pemerintah seharusnya lebih melihat eksistensi hukum adat sebagai kekayaan khazanah hukum nasional dan tidak dianggap sebagai penghalang pembangunan nasional.
\end{abstract}

Kata Kunci: Hak Ulayat, Pembangunan Hukum, Keadilan.

\begin{abstract}
The enforcement of custom-derived land rights through the adoption of law number 5 of 1960 about the Basic Agrarian Law Act and Agrarian ministerial regulation number 5 of 1999 directly provides expectations for equality towards the tenure and ownership of Indonesian customary law. However, in reality the positive law which regulates this right is still ambiguous and provides obscurity, which resulted in the arbitrary act by the government. This custom-derived land rights, which is the highest land rights of customary law, is oftenly being set out, or even seized by the government, for example in the case where the Government and PT Freeport seized this land right from the Amungme tribe in Papua. In the Agrarian law development, the government should have seen more in the aspect of the existence of customary law as a national law richness, and not consider it as a barrier of national law development.
\end{abstract}

Keywords: Custom-derived land rights, Law Development, Equality 


\section{PENDAHULUAN}

Keadilan sosial adalah yang dirumuskan oleh sila kelima dari pancasila. Keadilan tersebut ini bertujuan untuk mencapai perdamaian, kesejahteraan dan kemajuan dalam setiap komunitas dan Negara. ${ }^{1}$ Indonesia menganut demokrasi yang memiliki beberapa dasar yang harus ditegakkan, dan bagian untuk keadilan dalam menguasai agraria di Indonesia. ${ }^{2}$ Ketentuan bentuk pengelolaan agraria didasarkan pada Pasal 33 Ayat (3) UUD 1945 sebagai ketentuan dasar yang menyatakan:"Bumi, air dan kekayaan alam didalamnya dikuasai oleh Negara dan digunakan sebesar-besarnya untuk kemakmuran rakyat". ${ }^{3}$ Pasal tersebut mutlak diperuntukan untuk kesejahteraan rakyat Indonesia. Kesejahteraan rakyat yang adalah cerminan keadilan sosial sebagaimana nilai luhur keadilan sosial dalam pancasila harus dijalankan oleh Negara.

Dalam sebagian permukaan bumi dibatasi dengan sebidang tanah dimaksud adalah hak atas tanah. Di samping itu, hak atas tanah tidak meliputi tubuh bumi, air dan yang ada di dalamnya. Pengaturan tanah telah diatur dan ditegaskan pada pasal 4 UUPA. ${ }^{4}$ Pada konsepsi dan pelaksanaannya, haruslah dibatasi dengan tegas agar masa-masa yang datang dan apabila saatnya untuk berpikir mencari alternatif dari hak menguasai tersebut. Selain itu, perlunya pengaturan pemanfaatan, dan penggunaan tanah supaya terwujud hak atas tanah sebagai fungsi sosial. Fungsi sosial tersebut adalah kepentingan perorangan dan masyarakat adat tetapi bukan berarti kepentingan umum mendesaknya. ${ }^{5}$

\footnotetext{
${ }^{1}$ Deby Gemysa, "Implementasi Sila Kelima Keadilan Bagi Seluruh Rakyat Indonesia", $<$ https://www.kompasiana.com/bebefaradiba/implementasi-sila-kelima-keadilansosial-bagi-seluruh-rakyat-indonesia 552fcb6b6ea8344b3e8b4567>, diakses 19 Mei 2020.

${ }^{2}$ Jimly Asshidiqqie, Gagasan Kedaulatan Rakyat dalam Konstitusi dan Pelaksanaannya di Indonesia, (Ichtiar Baru, Jakarta: 1994), hal. 58 ayat (3)

${ }^{3}$ Indonesia, Undang-Undang Dasar Negara Republik Indonesia Tahun 1945, pasal 33

${ }^{4}$ Alif Abdurrahman, "Konsistensi Penerapan UU No. 5 Tahun 1960 terkait dengan Hak Milik atas Tanah bagi WNI Non Pribumi di Yogyakarta”, Jurnal Gema Keadilan, Vol. 6, Edisi (Agustus 2019), hal. https://ejournal2.undip.ac.id/index.php/gk/article/download/5627/2994.

${ }^{5}$ Marhcel R. Maramis, "Kajian Atas Perlindungan Hukum Hak ulayat Dalam Prespektif Hak Asasi Manusia”, Jurnal Hukum UNSRAT, Vol. 21, No. 4, (Juni 2013), hal. 2, diakses 23
} 
Namun, secara de facto, konflik agraria semakin meningkat dan melanda beberapa daerah di Indonesia. Dengan berbagai alasan pembangunan untuk masa depan kesejahteraan rakyat terancam punah. Berdasarkan data tahunan Konsorsium Pembaruan Agraria (KPA), telah terjadi peningkatan hingga dua kali lipat jumlah perselisihan agraria selama tahun 2017, dibandingkan tahun sebelumnya. Sesuai data yang dikeluarkan KPA, selama satu tahun lalu saja, terjadi lebih dari 1361 konflik agraria di seluruh Indonesia. ${ }^{6}$

Pada pengawasan di semua lingkungan suatu usaha, posisi yang masih pertama yaitu perkebunan. Perselisihan agraria pada tahun 2017 telah banyak di lingkungan usaha perkebunan yaitu sebanyak 208 atau 32 persen dari seluruh jumlah kejadian perselisihan. Posisi kedua yaitu ada di lingkungan usaha properti dengan 199 (30\%) jumlah kejadian konflik. Posisi ketiga ditempati pada infrastruktur dengan 94 perselisihan (14\%), disusul sektor pertanian dengan 78 (12\%) kejadian perselisihan. Seterusnya sektor kehutanan dengan jumlah 50 (11\%) perselisihan, sektor pesisir dan kelautan sebanyak 48 (10\%) perselisihan, dan terakhir sektor pertambangan dengan jumlah 40 (8\%) kejadian perselisihan yang terjadi sepanjang tahun $2017 .^{7}$

Dalam tulisan ini, penulis memfokuskan pada perihal pembangunan hukum mengenai konflik pertambangan yang bertentangan dengan hak ulayat Masyarakat Hukum Adat yang semakin meningkat. Menurut Van Vollenhoven, menyatakan bahwa hak atas tanah dari persekutuan hak ulayat itu sebagai suatu hak atas tanah dari berbagai perhimpunan hukum di Indonesia, yang tidak dapat dilepaskan untuk selama-lamanya dan tidak boleh diakui oleh perseorangan. Perbedaan ciri-ciri hak ulayat dengan hak miliknya yaitu persekutuan hukum dan berbagai anggotanya berhak menggunakan dan

Mei 2020, doi: https://media.neliti.com/media/publications/890-ID-kajian-atas-perlindunganhukum-hak-ulayat-dalam-perspektif-hak-asasi-manusia.pdf

${ }^{6}$ Estu Suryowati, '659 Konflik Agraria Tercatat Sepanjang 2017, Mencakup Lebih dari

500.000 Hektar", <http://nasional.kompas.com/read/2017/12/27/14592061/659-konflik-agrariatercatat-sepanjang-2017-mencakup-lebih-dari-500000>, diakses pada 27 Desember 2017

${ }^{7}$ KPA Tahun 2017, "Catatan Akhir Tahun 2017: Reforma Agraria Dibawah Bayang Investasi, Gaung Besar Dipinggir Jalan, http://kpa.or.id/assets/uploads/files/publikasi/d5a29catahu-2017-kpa.pdf, hal. 6. 
menikmati kenikmatan dari menggarap tanah pada daerah persekutuan hukum tersebut. ${ }^{8}$

Dapat dilihat dari tata susunan pemegang saham PT freeport Indonesia yakni 9,36\% dimiliki oleh pemerintah Republik Indonesia adalah PT Indocopper Investama dan Freeport MCMoran Copper \& Gold Inc. 81,28\%, dengan demikian bahwa keberadaan PT freeport di Negara Indonesia hanya memberikan hasil finansial terhadap pemerintah. Pada pemilik lahan Suku Amungme, pembagian saham tersebut tidak ada pembagian kepada hak ulayat masyarakat adatnya. ${ }^{9}$

Walaupun hak ulayat merupakan hak yang tidak bisa dilepaskan, namun dapat kita lihat pada prakteknya bahwa sampai sekarang ini masih banyak sengketa perampasan atas hak ulayat masyarakat adat oleh pemerintah, contohnya yang dialami oleh Suku Amungme di Papua, terdapat sengketa dimana pihak PT Freeport dan pemerintah merebut hak tanah adat di daerah Timika Papua. ${ }^{10}$ Kemudian, ada pula perampasan dan hasil lahan secara tawarmenawar dengan tidak transparan dan tidak independen, serta membohongi masyarakat adat tersebut. ${ }^{11}$ Hal tersebut membuktikan bahwa dalam perundang-undangan Agraria Indonesia masih terdapat stagnasi hukum, dan belum ada penerapan hukum yang dapat memberi keadilan bagi masyarakat adat Indonesia.

Pancasila yang merupakan grundnorm telah dicederai dengan konflikkonflik tersebut. Negara Republik Indonesia dalam pelaksanaan belum bisa

\footnotetext{
${ }^{8}$ Markus H Simarmata, "Hukum Nasional, Yang Responsif Terhadap Pengakuan dan Penggunaan Tanah Ulayat", Jurnal RechtsVinding, Vol. 7, No. 2, (Agustus 2018), https://rechtsvinding.bphn.go.id/ejournal/index.php/jrv/article/viewFile/251/184, diakses 23 Mei 2020, hal. 6 .

${ }^{9}$ Komnas HAM, "Laporan Tim Pemantuan Terkait Pengaduan Pelanggaran HAM Penguasaan atau Pengambilan Lahan Suku Amungme Oleh PT Freeport Indonesia”, Press Release, https://docs.google.com/document/d/1Y6boaCf349aWs fh9fPXQca8njMrqScOKwVFpA5rXX0 ledit, hal. 1.

${ }^{10}$ Kristian Erdianto, "Pemerintah dan Freeport Disebut Merampas Hak Tanah Adat Suku Amungme", $\quad<\underline{\text { http://nasional.kompas.com/read/2017/02/24/16342521/pemerint- }}$ $\underline{\text { ah.dan.freeport.disebut.merampas.hak.tanah.adat.suku.amungme> }}$, Diakses 24 Februari 2017

${ }^{11}$ Komnas HAM, “Jurnal Hak Asasi Manusia, Jurnal HAM”, Komnas HAM, Vol. 12, (2016), hal. 161, diakses 23 Mei 2020, doi: https://www.komnasham.go.id/files/20151102jurnal-ham-edisi-khusus-papua-\$MSS.pdf
} 
memberikan kesejahteraan sosial dan pengawasan kegiatan agraria yang secara konstitusional dipergunakan untuk kemakmuran rakyat. Sifat penting pancasila dalam sila kelima, adalah keadilan sosial kepada warga negara Indonesia harus dijadikan dasar pembangunan Indonesia. ${ }^{12}$ Maka dari itu, dalam tulisan ini penulis menyampaikan bahwa pembangunan hukum dalam perspektif hukum tanah adat, terutama mengenai hak ulayat, sangatlah diperlukan untuk mewujudkan keadilan bagi masyarakat dan juga untuk mencegah kesewenangwenangan yang dilakukan oleh negara, berdasarkan dengan Pancasila sila yang kelima.

\section{Perumusan Masalah}

Berdasarkan hal tersebut, tulisan ini akan membahas sebagai berikut:

1. Apakah hukum positif mengenai Hak Ulayat atas tanah adat yang berlaku sudah memberikan keadilan bagi masyarakat Indonesia?

2. Bagaimanakah keadilan yang seharusnya diberikan kepada Masyarakat Suku Amungme di Papua dalam sengketa perampasan Hak Ulayat oleh Pemerintah dan PT Freeport?

\section{Tujuan Penelitian}

Berkaitan dengan permasalahan pada rumusan masalah di atas, adapun tujuan yang ingin dicapai dalam penulisan jurnal ini antara lain :

1. Meningkatkan kesadaran pada masyarakat akan pentingnya Hukum Adat.

2. Memperoleh informasi mengenai hak ulayat serta hukum yang berlaku.

3. Mengidentifikasi kekosongan hukum yang terdapat pada peraturanperaturan yang masih berlaku

4. Menghimbau pemerintah agar lebih memperhatikan persoalan mengenai hak ulayat atas tanah masyarakat adat.

5. Meningkatkan rasa keadilan pemerintah dan masyarakat Indonesia sesuai dengan sila ke lima Pancasila

${ }^{12}$ Mohamad Toha Hasan, "Pancasila, Pembangunan dan Keadilan Sosial Bagi seluruh rakyat Indonesia", https://tohasan.wordpress.com/2017/06/01/pancasila-pembangunan-dankeadilan-sosial-bagi-seluruh-rakyat-indonesia/, diakses 23 Mei 2020. 


\section{Metode Penelitian}

Penelitian hukum normatif adalah penelitian hukum yang yang meletakkan hukum sebagai sebuah bangunan sistem norma. Menurut Soerjono Soekanto penelitian hukum normatif adalah:"Penelitian hukum yang dilakukan dengan meneliti bahan pustaka atau data sekunder belaka"13 Metode Penelitian yang digunakan adalah metode Kualitatif, yaitu penelitian tentang riset yang bersifat deskriptif dan cenderung menggunakan analisis. Proses dan makna lebih ditonjolkan dalam penelitian kualitatif. Landasan teori dimanfaatkan sebagai pemandu agar fokus penelitian sesuai dengan fakta di lapangan.Dalam penelitian kualitatif, penelitian berangkat dari teori menuju data, dan berakhir pada penerimaan atau penolakan terhadap teori yang digunakan. Patton ${ }^{14}$ mengatakan:

Qualitative research uses a naturalistic approach that seeks to understand phenomena in context - specific Settings, such as "real world setting [where] the researcher does not attempt to manipulate the phenomenon of interest.

Metode pendekatan yang digunakan dalam penulisan ini adalah yuridis normatif, karena dalam penulisan dilakukan antara lain: (a) Penafsiranpenafsiran hukum (penafsiran normatif dan otentik) terhadap pasal-pasal perundangan yang berkaitan dengan materi Hukum Agraria, Hukum Adat, dan Hukum Administrasi Negara. (b) Mencari dan menemukan teori-teori dari Filsafat Hukum yang berkaitan dengan aliran utilitarianisme dan ajaran Hukum pembangunan. (c) Konstruksi hukum melalui analogi terhadap perundangundangan yang berhubungan dengan penulisan ini.

Teknik pengolahan data sekunder dilakukan ini melalui studi pustaka Menurut Nazir teknik pengumpulan data dengan melakukan penelaahan terhadap berbagai buku, literatur, catatan, serta berbagai laporan yang berkaitan dengan masalah yang ingin dipecahkan. ${ }^{15}$

\footnotetext{
${ }^{13}$ Soerjono Soekanto dan Sri Mamudji, "Penelitian Hukum Normatif”, (Jakarta: PT Raja GrafindoPersada, 2006), hal. 24.

${ }^{14}$ Michael Patton, "Metode Evaluasi Kualitatif", (Yogyakarta: Pustaka Belajar, 2001), hal.39.

${ }^{15}$ Anonim, "Pengertian Studi Pustaka", Situs $<$ http://www.definisimenurutparaahli.com/pengertian-studi-pustaka/>, diakses pada 10 September 2017
} 
Tahap terakhir penulisan merupakan tahap penarikan kesimpulan dari semua data yang telah diperoleh. Penarikan kesimpulan atau verifikasi adalah usaha untuk mencari atau memahami makna/arti. keteraturan, pola-pola, penjelasan, alur sebab akibat. Sebelum melakukan penarikan kesimpulan terlebih dahulu dilakukan reduksi data, penyajian data dan serta menganalisis berdasarkan peninjauan kepustakaan. Penarikan kesimpulan merupakan tahap akhir dari kegiatan analisis data.

\section{PEMBAHASAN}

Hukum Positif Indonesia Mengenai Hak Ulayat atas Tanah Adat yang Berkeadilan bagi Masyarakat Indonesia

a. Hak ulayat berdasarkan Pasal 3 Undang-Undang Pokok Agraria.

Keberadaan pancasila merupakan fundamental, yang berfungsi sebagai dasar serta sebagai tujuan yang harus diperhatikan oleh setiap hukum atau peraturan yang ada, semua hukum yang berada dalam kawasan rezim grundnorm tersebut harus bisa mengait kepadanya.Grundnorm merupakan sumber nilai bagi adanya sistem hukum, sehingga ia merupakan bensin yang menggerakan seluruh sistem hukum

Dasar dibuatnya Undang-Undang Pokok Agraria, dikarenakan terjadi perubahan hukum agraria yakni pembangunan nasional dan berasal hukum agraria zaman kolonial. Secara teoritis, sifat nasional Undang-Undang Pokok Agraria (selanjutnya disebut UUPA) ditinjau pada pertimbangan yang mengatakan adanya kekurangan yang berlaku di ketentuan UUPA.

Kemudian, Indonesia perihal ketentuan mengenai Hak Ulayat masyarakat Hukum Adat diatur dalam Pasal 3 UUPA, yang berbunyi: "Dengan mengingat ketentuan-ketentuan dalam Pasal 1 dan Pasal 2 pelaksanaan hak ulayat dan 
pelaksanaan hak-hak serupa itu dari masyarakat-masyarakat Hukum Adat, sepanjang menurut kenyataannya masih ada, harus sedemikian rupa sehingga sesuai dengan kepentingan nasional dan Negara yang berdasakan atas persatuan bangsa serta tidak boleh bertentangan dengan Undang-Undang dan peraturanperaturan lain yang lebih tinggi." 16

UUPA merupakan termasuk hukum positif di Indonesia, dengan mana mengatur mengenai ketentuan tentang kepemilikan tanah setiap warga negara indonesia. Dalam pasal tersebut, subjek yang ditujukan adalah Masyarakat Hukum Adat, yang menurut Kusumadi Pudjosewojomerupakan masyarakat yang timbul secara spontan di wilayah tertentu yang berdirinya tidak ditetapkan atau diperintahkan oleh penguasa yang lebih tinggi atau penguasa lainnya, dengan atau solidaritas yang sangat besar diantara para anggotanya, yang memandang bukan anggota masyarakat sebagai orang luar dan menggunakan wilayahnya sebagai sumber kekayaan yang hanya dapat dimanfaatkan sepenuhnya oleh anggotanya. $^{17}$

Dalam UUPA tidak memberikan penjelasan yang jelas mengenai hak ulayat, kecuali menyebutkan bahwa yang dimaksud hak ulayat adalah beschikkingsrecht dalam kepustakaan hukum adat. ${ }^{18}$ Dalam istilah teknis yuridis hak ulayat adalah kewenangan yang menurut hukum adat dimiliki oleh masyarakat hukum adat atas wilayah tertentu yang merupakan lingkungan warganya yang memperbolehkan masyarakat untuk mengambil manfaat dari sumber daya alam termasuk tanah dalam wilayah tersebut bagi kelangsungan hidupnya. Dengan demikian hubungan antara masyarakat hukum adat dengan tanah/wilayahnya adalah hubungan menguasai, bukan hubungan memiliki sebagaimana halnya dalam konsep hubungan antara negara dengan tanah menurut Pasal 33 ayat (3) UUD 1945. ${ }^{19}$

\footnotetext{
${ }^{16}$ Indonesia, Undang-Undang Nomor 5 tahun 1960 tentang Peraturan Dasar Pokok-Pokok Agraria, LN tahun 1960 No. 104, TLN No.243.

${ }^{17}$ Kusumadi Pujosewojo, Pedoman pelajaran tata hukum Indonesia, (PT. Penerbitan Universitas - Jogjakarta, 1959), hal.56

${ }^{18}$ Urip Santoso, Hukum Agraria Kajian Komprehensif, (Jakarta: Kencana Prenadamedia Group, 2012), hal.82

${ }^{19}$ Rosmidah, "Pengakuan Hukum Terhadap Hak Ulayat Masyarakat Hukum Adat dan Hambatan Implementasinya.", $<$ https://onlinejournal.unja.ac.id/index.php/jimih/article/view/370>, Vol 2 No 4, Januari 2010, diakses tanggal 25 Februari 2018, hal. 96.
} 
Pasal 3 UUPA memberikan pengakuan terhadap hak ulayat masyarakat hukum adat, tetapi pelaksanaannya harus sesuai dengan kepentingan nasional dan Negara yang berdasarkan atas persatuan bangsa serta tidak boleh bertentangan dengan undang-undang dan peraturan yang lebih tinggi. ${ }^{20} \mathrm{Hal}$ ini berarti bahwa misalnya berdasarkan hak ulayat yang bersumberkan hukum adat, masyarakat-masyarakat hukum adat yang bersangkutan menghalangi pemberian hak guna usaha yang dilakukan oleh pemerintah, jika pemerintah hendak melaksanakan pembukaan secara besar-besaran dan teratur dalam rangka proyek-proyek besar untuk penambahan makanan, perkebunan dan transmigrasi, maka hak ulayat dari suatu masyarakat hukum adat tidak boleh dijadikan penghalang. Ini tidak dapat dibenarkan, dengan kata lain, kepentingan suatu masyarakat hukum adat harus selalu dapat dikesampingkan demi kepentingan nasional dan negara Hal tersebut bisa berakibatkan tidak memberikan keadilan kepada masyarakat Hukum Adat.

Jika ditinjau lebih dalam lagi, Pasal 3 UUPA ini sebenarnya sudah tidak dapat diaplikasikan, karena peraturan ini sudah tidak sesuai dengan keadaan modern yang sudah berkembang dan mengalami kemajuan. Pada masa Orde Baru, bahkan tidak ada Undang-Undang baru yang mengatur mengenai hak masyarakat hukum adat, yang ada hanyalah pada era Reformasi, dikeluarkan Peraturan Menteri Agraria/ Kepala BPN nomor 5 Tahun 1999 tentang Pedoman Penyelesaian Masalah Hak Ulayat Masyarakat Hukum Adat yang merupakan lex specialis dari pasal ini. Ini membuktikan bahwa kepastian hukum dan kemanfaatan hukum belum tercapai.

b. Peraturan Menteri Agraria/Kepala Badan Pertanahan Nasional Nomor 5 Tahun 1999 tentang Pedoman Penyelesaian Masalah Hak Ulayat Masyarakat Hukum Adat.

Dalam penyelesaian masalah hak ulayat terhadap masyarakat hukum adat, dengan mana mengingat bahwa menurut Ter Haar Murid, masyarakat hukum adat merupakan golongan masyarakat yang teratur, menetap di suatu daerah tertentu, mempunyai kekuasaan sendiri, dan mempunyai kekayaan sendiri

\footnotetext{
${ }^{20}$ Abd. Rahman dan Baso Madiong, Politik Hukum Pertanahan (suatu kajian historis dan yuridis), (CELEBES MEDIA PERKASA, 2017), hal.79
} 
baik berupa benda yang terlihat maupun yang tidak terlihat, dimana para kelompok tersebut bersatu dan masing-masing mengalami kehidupan dalam masyarakat sebagai hal yang wajar menurut kodrat alam dan tidak seorangpun diantara para anggota itu mempunyai pikiran atau kecenderungan untuk membubarkan.

Bagian dari hukum positif mengingat juga bahwa hukum adat itu diatur di hukum Indonesia dengan mana mempunyai kekhasan pada setiap lembaga hukumnya. Hukum adat yang dimaksud disini mengenai pengaturan hak atas tanah yang terbagi menjadi 2 (dua) hal yaitu, hak mengenai persekutuan hukum dan hak perseorangan.

Ketika zaman orde baru yang penuh dengan penekanan, ancaman dan sebagainya masyarakat tidak berani mengeluarkan pendapat yang sifatnya tidak setuju dengan kebijaksanaan pemerintah, apalagi menentangnya karena akan mengakibatkan fatal bagi yang bersangkutan.

Setelah era orde baru, maka muncullah era reformasi. Reformasi terjadi di segala bidang kehidupan, sehingga di dalam setiap kesempatan akan selalu keluar istilah reformasi dimana rakyat mulai berani mengeluarkan isi hati dan pendapatnya bahkan kadang-kadang rakyat telah berani melakukan hujatanhujatan yang ditujukan kepada pemerintah sehingga seakan-akan reformasi identik dengan kebebasan yang tanpa batas, termasuk dalam hal ini adalah mengungkit kembali eksistensi hak guna usaha yang berasal dari hak ulayat masyarakat hukum adat. $^{21}$ Oleh karena pemerintah dilakukan dengan mengeluarkan Peraturan Menteri Negara Agraria/Kepala BPN Nomor 5 tahun 1999 tentang Pedoman Penyelesaian Masalah Hak Ulayat Masyarakat Hukum Adat.

Pentingnya adanya sebuah sistem norma yang sebagaimana menurut Kelsen. Dalam norma merupakan pernyataan yang menekankan dari sisi das sollen dilakukan dalam menyertakan beberapa peraturan tentang apa yang harus dilakukan . Kemudian, berbagai adalah produk dan aksi manusia yang deliberatif. Perihal Undang-undang yaitu yang berisi umum untuk menjadi

\footnotetext{
${ }^{21}$ Syafril, "kedudukan hak ulayat yang telah menjadi hak guna usaha setelah berlakunya peraturan menteri negara agraria Nomor 5 tahun 1999”, < http://ejournal.uajy.ac.id/420/1/2EAH05020.pdf >, Juli 2010, hal.34
} 
pedoman atau dasar bagi setiap perilaku individu dalam bermasyarakat. Adanya aturan itu guna menjadi pembatasan untuk masyarakat dalam melakukan kebijakan terhadap individu.

Meskipun Peraturan Menteri Agraria ini dalam rangka dibuat untuk memasukkan perihal kosongnya perundang-undangan pada kritik tekanan dari berbagai masyarakat adat, peraturan ini masih memiliki keterbatasan dan ambiguitas yang membuatnya tidak dapat dilaksanakan sepenuhnya untuk menyelesaikan permasalahan hak ulayat masyarakat adat. ${ }^{22}$

Seperti pada niat untuk membereskan permasalahan tanah ulayat malah dibatasi pada tanah-tanah yang diatasnya tidak terdapat hak-hak atas tanah menurut UUPA. Kriteria keberadaan masyarakat adat yang diatur dalam peraturan ini juga belum menampung gerak dari internal dan eksternal yang telah mendorong perkembangan komunitas masyarakat adat. Kurangnya terhadap pandangan keadilan transisional transitional justice tidak membuat peraturan itu digunakan guna memeriksa kebijakan yang salah di masa lalu.

Dari yang pernah dialamai dari beberapa komunitas membuktikan bahwa untuk memperoleh Perda pengakuan hak ulayat tidaklah mudah. Anggota DPRD adalah sebagian masyarakat adat perlu melakukan tawar-menawar dengan politikus lokal. Selain itu masyarakat adat juga mencoba mengatasi persoalan sektoralisme pengelolaan sumber daya alam yang diturunkan dari pemerintah pusat dengan cara melakukan negosiasi dengan dinas kehutanan di daerah. penelitian ilmiah yang dilakukan oleh Wiratraman dkk, mengemukakan bahwa sumber daya alam mempengaruhi berbagai faktor yaitu dari ketidakserasian peraturan perundang-undangan.

Pada berbagai macam tafsiran terhadap pengakuan hukum, dominasi penggunaan hukum dan institusi negara dalam penguasaan dan pengaturan sumber daya alam, serta kepentingan-kepentingan politik ekonomi yang melatarbelakangi segala kebijakan pusat dan daerah. ${ }^{23}$ Hal ini membuktikan bahwa keadilan belum berpihak dengan masyarakat Hukum Adat yang ditandai

\footnotetext{
${ }^{22}$ Noer Fauzi Rachman (et. al.), "Kajian Kritis atas Peraturan Menteri Agraria/ Kepala Badan Pertanahan Nasional Nomor 5 Tahun 1999 tentang Pedoman Penyelesaian Permasalahan Hak Ulayat Masyarakat Hukum Adat", Kertas Kerja Epistema No.01/2012, hal.16, doi: http://epistema.or.id/kajian-kritis-atas-peraturan-menteri-agraria/

${ }^{23}$ Noer Fauzi Rachman (et.al.), Ibid, hal.30
} 
dari sulitnya masyarakat Adat untuk memperoleh hak ulayatnya yang padahal telah diwariskan secara turun temurun dengan maksud untuk pemenuhan kepentingan kepada Masyarakat Hukum Adat.

Maka dari itu, diperlukannya pembangunan hukum yang lebih efektif dan pengadopsian atau pembuatan Undang-Undang baru untuk mengatur persoalan Hak Ulayat masyarakat Hukum Adat secara jelas, tidak memberikan kesewenang-wenangan pada pemerintah, dan memberikan keadilan yang tertinggi kepada Masyarakat Hukum Adat di seluruh Indonesia.

Sebagai tambahan, hak ulayat masyarakat Adat yang merupakan beschikkingsrecht hanya bergantung pada tindakan sepihak oleh Pemerintah. Pada praktiknya sekarang ini, pemerintah lebih mencondong kepada investorinvestor asing dan mengabaikan kepentingan masyarakat Hukum Adat. Berdasarkan pendapat oleh Mochtar Kusumaatmadja, hal ini berarti pemerintah mengabaikan kepentingan-kepentingan masyarakat Hukum Adat, dengan begitu terdapat ketidaksesuaian dengan Pancasila sila yang ke lima yang menyatakan "keadilan sosial untuk seluruh rakyat Indonesia".

Pemerintah seharusnya membantu menjaga dan melestarikan tanah adat daerah-daerah di Indonesia untuk kepentingan hidup masyarakat Hukum Adat seperti pertanian, perkebunan, dan lain-lain dengan cara memfasilitasi masyarakatnya untuk mengelola tanah adat tersebut, bukan malah menggunakan kewenangannya untuk menjual tanah dan lahan masyarakat Hukum Adat beserta harta kekayaan yang terdapat di dalamnya kepada investor-investor asing untuk pertambangan semata-mata demi memperoleh keuntungan.

Keadilan yang Seharusnya Diberikan kepada Masyarakat Suku Amungme di Papua dalam Kasus Perampasan Hak Ulayat oleh Pemerintah dan PT Freeport. Sebelum mengkaji keadilan yang seharusnya diberikan kepada masyarakat suku Amungme di Papua, mengingat bahwa konstitusi kita sebagai sumber hukum tertinggi yaitu Undang-Undang Dasar Negara Republik Indonesia Tahun 1945 pada pasal 18B ayat (2) telah menjamin bahwa : Negara mengakui dan menghormati kesatuan-kesatuan masyarakat hukum adat beserta hak-hak tradisional sepanjang masih hidup dan sesuai dengan perkembangan masyarakat dan prinsip Negara Kesatuan Republik Indonesia, yang diatur dalam 
Undang-Undang. ${ }^{24}$ Atas pasal tersebut, maka negara mengakui dan menjunjung tinggi hak tradisional masyarakat hukum adat, salah satunya yaitu hak ulayat atas tanah masyarakat adat.

Jika pemenuhan konstitusi secara rasa keadilan terhadap hak ulayat sudah tidak ada lagi, maka hal tersebut menjadi kesadaran bersama.Hak ulayat itu bagian dari seperangkat hak dan kewajiban pendukung utama penghidupan dan kehidupan masyarakat yang bersangkutan sepanjang masa. Menurut Boedi Harsono tugas dan kewajiban tersebut ada yang termasuk ke dalam bidang hukum perdata yaitu:

1. Berhubungan dengan hak bersama;

2. Termasuk ke dalam bidang hukum publik

Keberadaan hak ulayat sebagaimana telah diatur peraturan perundangundangan yaitu seharusnya dicantumkan, kriteria eksistensi hak ulayat dan hak dan kewajiban masyarakat adat yang merupakan hak pemegang yang mengelolanya. Sehingga terwujudnya hak-hak masyarakat dalam menghormati maupun melindungi hak -hak tersebut. Pada bidang hukum publik yang berhubungan untuk mengelola, mengatur, dan memimpin peruntukan, penguasaan, penggunaan, dan pemeliharaannya. Selain itu B.Ter Haar Bzn mengemukakan, bahwa hak ulayat merupakan hak perhimpunan hukum atas tanah yang berlaku baik ke dalam maupun ke luar. Pernyataan berlaku ke dalam artinya bahwa hak persekutuan hukum untuk mengatur pemakaian tanah bagi anggota-anggotanya sedemikian rupa sehingga setiap anggota persekutuan desa itu mendapat bagian tanahnya masing-masing dengan pembatasan-pembatasan bagi kepentingan desa. ${ }^{25}$

Berangkat kekuatan berlaku ke dalam, adalah suatu kewajiban dari penguasa adat yang bersumber dari hak ulayat untuk memelihara kesejahteraan dan kepentingan-kepentingan anggota masyarakat umumnya, menjaga dan mencegah perselisihan mengenai pemakaian tanah, dan kalau terjadi persengketaan, penguasa adat wajib menyelesaikannya.

\footnotetext{
${ }^{24}$ Indonesia, Undang-Undang Dasar Negara Republik Indonesia Tahun 1945, pasal 18B ayat (2)

${ }^{25} \mathrm{H} \quad$ Ismi, "Penguasaan dan Pemilikan Tanah", $\quad$ http://ejournal.uajy.ac.id/361/3/2MIH01442.pdf> , Febuari 2012, hal.30
} 
Kekuatan berlaku ke luar diartikan bukan anggota persekutuan hukum ada hanya mengerjakan tanah dengan seizin dari penguasa hukum adat dengan membayar kerugian sebagai suatu pengakuan atas hak persekutuan hukum adat tersebut. Izin yang diberikan ini hanya terbatas pada hak pakai saja, karena orang asing tidak diperkenankan untuk mempunyai hak milik di atas tanah ulayat. Hak pakai itu pun batas waktu berlakunya untuk satu kali panen saja atau untuk beberapa kali panen. ${ }^{26}$

Orang asing yang menggunakan tanah tanpa seizin masyarakat Hukum Adat pemilik Hak Ulayat, sebenarnya telah dikategorikan sebagai melakukan suatu delict atau kejahatan, yaitu perampasan hak. ${ }^{27}$ Seharusnya setiap orang atau sekelompok orang selain masyarakat adat tersebut, minta izin kepada sekitar masyarakat adatnya. Ketiadaan tegas dan jelas dari hukum dikarenakan ketidakmauan dan ketidakmampuan negara terhadap pengakuan hak masyarakat adat.

Disisi lain dikeluarkannya Undang-undang Nomor 21 Tahun 2001 Tentang Otonomi Khusus Papua yang saat ini sudah diubah dengan Peraturan Pemerintah Pengganti Undang-Undang Nomor 1 Tahun 2008 Tentang Perubahan atas Undang-undang Nomor 21 Tahun 2001 Tentang Otonomi Khusus Papua masih adanya berbagai perbuatan menyimpang kebijakan negara terhadap masyarakat Papua khususnya masyarakat hukum adat Suku Amungme di Papua mengenai hak ulayat atas tanah. ${ }^{28}$

Kemudian, sejak Freeport beroperasi, suku Amungme yang mendiami Gunung Nemangkawi atau dikenal Grasberg di Timika, mengalami kekerasan tak berkesudahan. Di Gunung suci mereka dikeruk, habis ditambang perusahaan asal Amerika Serikat, yaitu PT Freeport, tanpa persetujuan sang pemilik tanah ulayat. $^{29}$

${ }^{26} \mathrm{Ibid}$, hal.31

${ }^{27}$ John Salindeho, Masalah Tanah Dalam Pembangunan, (Jakarta: Sinar Grafika, 1987), hal.279

${ }^{28}$ Agus Sumule, Mencari Jalan Tengah Otonomi Khusus Provinsi Papua, (Jakarta: Gramedia Pustaka Utama, 2000), hal.69

${ }^{29}$ Quinawaty Pasaribu, "Tersingkir Perlahan Dari Tanah Leluhurnya, Begini Nasib Suku Amungme di Papua", < http://www.tribunnews.com/nasional/2017/03/21/tersingkir-perlahan-daritanah-leluhurnya-begini-nasib-suku-amungme-di-papua>, Diakses pada: 21 Maret 2017 
Data pelanggaran hasil penelitian Komnas HAM perihal permasalah di pertambangan PT freeport terhadap suku Amungme sebagai yang memiliki tanah ulayat, bahwa kontrak karya ditandatangani oleh Pemerintah Indonesia dengan PT Freeport pada tanggal 7 April Tahun 1967 yang tidak melibatkan pihak masyarakat ada setempat.

Adapun pada zaman era rezim Soeharto hingga rezim pemerintah Joko Widodo, pemerintah aktif menerbitkan izin-izin perihal izin dan pemanfaatan hasil hutan dan tanah di Papua, yang diberikan kepada sekumpulan perusahaan nasional dan keluar dari nasional untuk penebangan hasil hutan kayu, perkebunan skala luas dan pertambangan, namun pemberian hak dan izin pemanfaatan tersebut dilakukan tanpa ada konsultasi dan persetujuan masyarakat, terjadi adanya merebut hak, pelanggaran HAM dan kekerasan, ancaman, mengalami diskriminasi, manipulasi, kerusakan lingkungan dan penbangan hutan yang luas.

Masyarakat kehilangan sumber mata pencaharian dan mendapat gaji buruh murah, kompensasi tidak adil, kehilangan dan kesulitan mengakses sumber pangan yang sehat, terjadi malapetaka banjir dan busung lapar, mereka kehilangan sumber obat-obatan dan identitas kebudayaan. Kehidupan orang asli Papua yang berdiam di sekitar proyek semakin sulit, miskin dan terancam punah. ${ }^{30}$

Terdapat pernyataan dari Komisi Nasional Hak Asasi Manusia (selanjutnya disebut Komnas HAM) menyatakan bahwa negara Indonesia serta PT Freeport Indonesia (selanjutnya disebut PTFI) telah melakukan perampasan dan perbuatan menguasai secara sewenang-wenang terhadap hak ulayat suku Amungme.

Pembuktian atas tindakan perampasan itu diungkapkan oleh Komnas $\underline{\text { HAM }}$ setelah melakukan pemantauan dan penyelidikan langsung selama dua tahun sejak 2015. Hasilnya, tidak pernah ditemukan bukti transaksi jual beli kepemilikan tanah baik antara pemerintah dengan suku Amungme maupun PTFI dengan Amungme. Penguasaan dilakukan pemerintah dan PTFI atas sumber daya Suku Amungme menerjang sejumlah peraturan perundang-undangan, yakni

\footnotetext{
${ }^{30}$ Mark Imbiri, Loc.cit.
} 
Pasal 18B ayat (1), Pasal 28I ayat (3) UUD 1945, Pasal 6 ayat (2) UU HAM dan Perda Papua No. 22 Tahun 2008 tentang Hak Ulayat Masyarakat Hukum Adat, dan Pasal 1 dan 5 deklarasi HAM PBB tentang Hak Penduduk Asli. Negara yang seharusnya menjadi pelindung dan menjamin penegakkan HAM sesuai UU Nomor 39 Tahun 1999, justru menjadi aktor utama pelanggaran hak masyarakat adat suku Amungme. ${ }^{31}$

Dalam kasus ini, pemerintah telah bertindak sewenang-wenang dan mengabaikan keadilan bagi masyarakat Suku Amungme serta melanggar Hak mereka. Terlihat sangat jelas bahwa pembangunan hukum dalam persoalan ini belum memadai dan belum bisa menyelesaikan persoalan mengenai Hak Ulayat Suku Amungme.

Atas kejadian tersebut apakah sebenarnya pemerintah dan PTFI telah melakukan delik kejahatan atau tidak serta apakah itu termasuk pelanggaran HAM. Dengan demikian, sebenarnya Negara kita ini membutuhkan badan Konstitusi yang lebih kuat untuk mengawasi kinerja pemerintah serta aparat penegak hukum yang memadai agar tidak terjadi penyalahgunaan kekuasaan. Pembangunan hukum dari aspek kepentingan masyarakat Hukum Adat masih sering disepelekan, dan pemerintah terlalu memfokuskan kepada investor dan perusahaan asing yang sebenarnya hanya merugikan Negara Indonesia ini.

Berbicara mengenai keadilan untuk setiap warga negara, pasti tidak jauh dari adanya peran pemerintah atau negara yang memberikan pengawasan yang tepat dan benar serta didasarkan pada ketentuan hukum positif Indonesia yaitu termasuk kepastian hukum yang diberlakukan terhadap kepemilikan tanah atau agraria.

Oleh karena itu perlu adanya hukum yang penuh dengan makna sehingga bisa mengakomodir secara nyata di masyarakat dengan mana telah diatur oleh norma hukum. Menurut aliran utilitarianisme atau disebut kemanfaatan sebagai aliran yang memposisikan manfaat dari tujuan utama hukum tersebut. Kemanfaatan yang dimaksud itu adalah memberikan kebahagiaan kepada masyarakat atau tidak.

\footnotetext{
${ }^{31}$ Mutiul Alim, "Komnas HAM Sebut Pemerintah dan PT Freeport Rampas Lahan Suku Amungme", <http://www.jurnas.com/artikel/14230/Komnas-HAM-Sebut-Pemerintah-dan-PTFreeport-Rampas-Lahan-Suku-Amungme/>, Diakses 24/02/2017
} 
Dengan demikian implementasi keadilan itu ada terdapat 3 bagian perwujudan kepastian hukum, kemanfaatan, dan penegakkan perlindungannya seperti apa. Kemudian, peran Negara adalah penyelenggara terpenting, dikarenakan secara maksimal dalam pemenuhan kewajiban guna menghormati, dan melindungi hak asasi masyarakat adat tersebut. Dari persoalan mengenai kasus perampasan Hak ulayat di Papua, disinilah peran KOMNAS HAM untuk turut serta membantu dalam mengenai pembangunan Hukum yang dapat memberikan keadilan masyarakat adat dan merekomendasikan PT. Freeport Indonesia untuk segera menyelesaikan tuntutan ganti rugi tanah Amungme.

\section{PENUTUP}

\section{Kesimpulan}

Berdasarkan rumusan masalah yang telah dirumuskan sebelumnya, penulis telah mendapatkan beberapa kesimpulan untuk menjawab permasalahan tersebut, antara lain:

1. Adanya dua Hukum positif di Indonesia mengenai Hak ulayat atas tanah Adat, yaitu: Pada pasal 3 Undang-Undang Pokok Agraria. Jika ditinjau lebih dalam lagi, Pasal 3 UUPA ini sebenarnya sudah tidak dapat diaplikasikan, karena peraturan ini sudah tidak sesuai dengan keadaan zaman yang maju. b) Dikeluarkan Peraturan Menteri Agraria/Kepala Badan Pertanahan Nasional Nomor 5 Tahun 1999 tentang Pedoman Penyelesaian Masalah Hak Ulayat Masyarakat Hukum Adat.

Hukum positif yang berlaku mengenai kepemilikan tanah tersebut merupakan hanya kepastian hukum, tidak melaksanakan keadilan mana yang dimaksud dalam keadilan itu adalah keadilan untuk sosial bagi seluruh warga Indonesia, tanpa terkecuali. Peraturan Menteri Agraria ini dibuat untuk mengisi kekosongan perundang-undangan, tetapi peraturan ini masih memiliki keterbatasan dan ambiguitas yang membuatnya tidak dapat dilaksanakan sepenuhnya untuk menyelesaikan permasalahan hak ulayat masyarakat adat.

Kriteria keberadaan masyarakat adat yang diatur dalam peraturan ini juga belum menampung dinamika internal dan eksternal yang telah mendorong 
perkembangan komunitas masyarakat adat. Kurangnya perspektif keadilan transisional (transitional justice) tidak membuat peraturan itu digunakan untuk mengoreksi kebijakan yang keliru di masa lalu.Hal di atas ketidakserasian hukum positif yang berlaku dan penerapan secara nyata hukumnya, dan adanya jaminan hukum positif itu akan mewujudkan kepastian hukum maupun keadilannya.

2. Keadilan yang seharusnya diberikan kepada masyarakat Papua yaitu, dalam kasus ini, pemerintah telah bertindak sewenang-wenang dan mengabaikan keadilan bagi masyarakat Suku Amungme serta melanggar Hak mereka. Terlihat sangat jelas bahwa pembangunan hukum dalam persoalan ini belum memadai dan belum bisa menyelesaikan persoalan mengenai Hak Ulayat Suku Amungme.

Sebenarnya pemerintah dan PTFI telah melakukan delik kejahatan serta pelanggaran HAM. Maka sebenarnya Negara kita ini membutuhkan badan Konstitusi yang lebih kuat untuk mengawasi kinerja pemerintah serta aparat penegak hukum yang memadai agar tidak terjadi penyalahgunaan kekuasaan.

Dari persoalan mengenai kasus perampasan Hak ulayat di Papua, disinilah peran KOMNAS HAM untuk turut serta membantu dalam mengenai pembangunan Hukum yang dapat memberikan keadilan masyarakat adat dan merekomendasikan PT. Freeport Indonesia untuk segera menyelesaikan tuntutan ganti rugi tanah Amungme.

\section{Saran}

Untuk pengembangan lebih lanjut maka kami memberikan saran yang bermanfaat dan dapat membantu memperluas pemikiran pembaca, yaitu :

1. Menyadari bahwa hukum positif Indonesia mengenai Hak Ulayat atas Tanah Adat masih belum bisa memberikan keadilan bagi Masyarakat Indonesia, saran dari kami adalah supaya pemerintah lebih memperhatikan aspek pembangunan hukum dalam sisi Hukum Agraria masyarakat adat. Kami menghimbau agar badan legislatif Negara Indonesia dapat merancang 
Undang-Undang mengenai Hak Ulayat yang lebih memusatkan perhatian terhadap kepentingan masyarakatnya. Kami menulis ini dengan harapan agar masyarakat Hukum Adat dapat memperoleh keadilan yang seharusnya didapatkan, dan menikmati haknya yang telah diatur secara turun temurun tanpa gangguan dari pemerintah.

2. Dalam sengketa perampasan Hak Ulayat masyarakat suku Amungme, Pemerintah telah dibutakan dengan keuntungan yang dapat diperoleh dari perusahaan asing seperti PT Freeport, dan melanggar hak masyarakat adatnya. Sumber daya alam yang dijual kepada investor asing hanya akan merugikan bangsa Indonesia kedepannya. Seharusnya pemerintah membantu masyarakat Hukum Adat untuk mengelola tanah yang diatasnya terdapat hak Ulayat, sehingga rakyat Indonesia dapat terus menikmati kekayaannya atas sumber daya alam yang dimilikinya. Maka dari itu, mengenai perbuatan yang telah dilakukan oleh pemerintah dan PT Freeport, menurut kami penggantian kerugian tidaklah cukup, badan konstitusi NKRI harus menegakkan keadilan dengan memberi sanksi yang efektif kepada pihak-pihak yang telah melakukan suatu pelanggaran hukum, seperti hukuman penjara, sehingga pelanggaran tersebut tidak akan terulangi lagi seiring berjalannya waktu. 


\section{DAFTAR PUSTAKA}

\section{BUKU}

Alting, Husen. Dinamika Hukum dalam Pengakuan dan Perlindungan Hak Masyarakat Hukum Adat Atas Tanah Yogyakarta: Laks Bang PRESSindo,2010.

Asshiddiqie, Jimly, Gagasan Kedaulatan Rakyat dalam Konstitusi dan Pelaksanaanya di Indonesia, Jakarta: Ichtiar Baru, 1994.

Darmodiharjo, Darji, dan Shidarta. Pokok-pokok Filsafat Hukum: Apa dan Bagaimana Filsafat Hukum Indonesia. Cetakan I. Jakarta: Gramedia Pustaka Utama. 1995.

Erwin, Muhammad. Filsafat Hukum (Perkembangan dan Dinamika Masalah), Jakarta: Rajawali Pers, 2011.

G.Kartasapoetra, et.al. Hukum Tanah, Jaminan Undang-Undang Pokok Agraria Bagi Keberhasilan Pendayagunaan Tanah, Jakarta: Bina aksara, 1985.

Harsono, Boedi. Hukum Agraria Indonesia, Himpunan PeraturanPeraturan Hukum Tanah, Jakarta: Djambatan, 2004.

Huijbers, Theo. Filsafat Hukum Dalam Lintasan Sejarah, Yogyakarta: Kanisius, 1982.

Johnson, S. Alvin, Sosiologi Hukum, Cetakan III, Jakarta: Rineka Cipta, 2006.

Kusumaatmadja, Mochtar, Konsep-Konsep Hukum Dalam Pembangunan (Kumpulan Karya Tulis), Bandung: Penerbit Alumni, 2002.

Marzuki, Mahmud Peter, Pengantar Ilmu Hukum, Jakarta: Kencana, 2008

Mertokusumo, Sudikno, Penemuan Hukum, Bandung: Citra Aditya Bakti, 2009.

Patton, Michael, Metode Evaluasi Kualitatif, Yogyakarta: Pustaka Belajar, 2001.

Santoso, Urip, Hukum Agraria Kajian Komprehensif, Jakarta: Kencana Prenadamedia Group, 2012.

Salindeho, John, Masalah Tanah Dalam Pembangunan, Jakarta: Sinar Grafika, 1987.

Soekanto, Soerjono dan Sri Mamudji, Penelitian Hukum Normatif. Cetakan IX. Jakarta: PT Raja GrafindoPersada, 2006.

\section{PERATURAN PERUNDANG-UNDANGAN}

Undang-Undang Dasar Negara Republik Indonesia. Tahun 1945 pada pasal 33 ayat (3)

Undang-Undang Dasar Negara Republik Indonesia. Tahun 1945 pada pasal 18B ayat (2)

Undang-Undang Nomor 5 tahun 1960 tentang Peraturan Dasar PokokPokok Agraria. UU Nomor 5 tahun 1960 LN No. 104 tahun 1960, TLN No.243 Indonesia. 


\section{JURNAL}

HAM, Komnas. "Laporan Tim Pemantuan Terkait Pengaduan Pelanggaran HAM Penguasaan atau Pengambilan Lahan Suku Amungme Oleh PT Freeport Indonesia”, Press Release, https://docs.google.com/document/d/1Y6boaCf349aWs_fh9fPXQca8njMrqScO KwVFpA5rXX0/edit

Rosmidah, "Pengakuan Hukum Terhadap Hak Ulayat Masyarakat Hukum Adat dan Hambatan Implementasinya.", $<\underline{\text { https://online- }}$ journal.unja.ac.id/index.php/jimih/article/view/370>, Vol 2 No 4 (Januari 2010). Diakses tanggal 25 Februari 2018

Syafril, "kedudukan hak ulayat yang telah menjadi hak guna usaha setelah berlakunya peraturan menteri negara agraria Nomor 5 tahun 1999", http://e-journal.uajy.ac.id/420/1/2EAH05020.pdf , (Juli 2010)

Ismi, H "Penguasaan dan Pemilikan Tanah", $<$ http://ejournal.uajy.ac.id/361/3/2MIH01442.pdf> , (Febuari 2012)

Artajaya, Eka Wayan I, "PENGUATAN KEWENANGAN PENGADILAN ADAT DALAM PENYELESAIAN SENGKETA TANAH ULAYAT (LABE PURA): STUDI PADA MASYARAKAT ADAT DI KABUPATEN GIANYAR BALI.", $<$ http://e-journal.uajy.ac.id/8875/3/2MIH02207.pdf>, (Maret 2016).

Christian Siregar, Pancasila, Keadilan Sosial, dan Persatuan Indonesia, Vol. 5, (April 2014). Hal. 110

\section{WEBSITE}

Gemysa, Deby, "Implementasi Sila Kelima Keadilan Bagi Seluruh Rakyat Indonesia", $<$ https://www.kompasiana.com/bebefaradiba/implementasisila-kelima-keadilan-sosial-bagi-seluruh-rakyatindonesia 552fcb6b6ea8344b3e8b4567>

Konsorsium Pembaruan Agraria Tahun 2017, "KPA Launching Catatan Akhir Tahun 2017, <http://www.kpa.or.id/news/blog/kpa-launching-catatanakhir-tahun-2017/>

Erdianto, Kristian, "Pemerintah dan Freeport Disebut Merampas Hak Tanah Adat Suku Amungme", $<$ http://nasional.kompas.com/read/2017/02/24/16342521/pemerintah.dan.freepor t.disebut.merampas.hak.tanah.adat.suku.amungme $>$ 